\title{
IAMJ
}

INTERNATIONAL AYURVEDIC MEDICAL JOURNAL

\section{NEW DIMENSIONS OF AYURVEDA IN THIS COVID-19 ERA}

\author{
Sandeep Singh Tiwari' ${ }^{1}$, Mamta Masram², Prakhar Goyal $^{3}$ \\ ${ }^{1}$ Assistant Professor, Department of Rog Nidana Evum Vikruti Vigyana at DAMCH, Bareilly, Uttar Pradesh, India \\ ${ }^{2}$ Assistant Professor, Department of Samhita and Siddhanta, DAMCH, Daudhar, Bareilly, Uttar Pradesh, India \\ ${ }^{3} 2^{\text {nd }}$ Year, DAMCH, Bareilly, Uttar Pradesh, India
}

Corresponding Author: stiwari423@gmail.com

https://doi.org/10.46607/iamj07p5012020

(Published online: November 2020)

Open Access

(C) International Ayurvedic Medical Journal, India 2020

Article Received: 28/09/2020 - Peer Reviewed: 22/10/2020 - Accepted for Publication: 30/10/2020

Check for updates

\section{ABSTRACT}

Ayurveda is the Science of healing and a mere ancient medicinal text instead. It is a way of perceiving a healthy lifestyle. It primarily focuses on improving the lifestyle which can naturally heal the body and talks of medicines lately. This natural healing is the reason that everyone is looking at it hopefully at present conditions. Out of infinite healing techniques of Ayurveda some of the best are discussed here. Study of different principles of Ayurveda with its different prophylactic as well as curative approach, which shows the predominance of Ayurveda from time immemorial till today. Ayurveda has a broad category of techniques which can be used as prophylactic measures. This list consists of numerous methods and techniques that can help maintaining and achieving healthy lifestyle. This technique begins with the proper daily routine. A case presentation of a patient aged 43 years, an investor banker in New York, United States of America (USA), with a height of $193 \mathrm{~cm}$ and weighing $94.3 \mathrm{~kg}$ found corona positive. On the first day of falling ill contacted his Ayurvedic Vaidya in Chennai on the telephone, for a consultation and started on Ayurvedic medication for his complaints. This case proved that in these chemicals dominating era it has become a prerequisite requirement to collaborate with Ayurveda for a better and convenient lifestyle. Also mentioning different ways in which Ayurveda is helping today, with a special emphasis on the cure of covid19 patient through Ayurveda.

Keywords: Ayurveda, Parivarjana, Pathyavyavastha, Rasayana. 


\section{INTRODUCTION}

Ayurveda is the Science of healing and a mere ancient medicinal text instead. It is a way of perceiving a healthy lifestyle. It primarily focuses on improving the lifestyle which can naturally heal the body and talks of medicines lately. This natural healing is the reason that everyone is looking at it hopefully at present conditions. In Charak Samhita there is a classical reference of pandemic ${ }^{[1]}$ which describes the various reasons, characteristics and prevention of pandemics. It describes social disciplinary actions as lifesaving management during pandemics. Various management and concepts have been discussed in various ancient texts. Enough principles and techniques are formulated to establish good immune power and ensure good health. In the course of this pandemic from prophylaxis to various clinical trials Ayurveda has played a significant role. Various decoctions, proper use of spices, use of rejuvenators like Chawanprash has provided a major positive impact on the population till now and a few Ayurvedic clinical trials are currently in process. Some treatments using Sudarshanchurna and Sitopaladichurna are successfully given. In various clinical trials use of Ashwagandha, Giloya, Tulsi are done as well. The primary principle of Ayurveda is to keep a person disease free. However, even after the proper preventions if one falls sick, Ayurveda suggests proper medicines to one ${ }^{[2]}$. It advises preventive methods up to the mark and further appropriate dietary practices. We can see this phenomenon in the context of treatment as well where Pathyavyavastha and Nidaanparivarjan principles are used ${ }^{[3]}$. Ayurvedic principles are themselves opening up new dimensions for it. It is very important for us to understand a few of the basic principles on which Ayurveda depends so that we can have an insight in this magical science of healing. Basic principles of Ayurveda in the perceptive of health and immunity are as follow:

Tridosha: Ayurveda runs around this principle. This concept tells about 3 bodily humours viz. Vata, Pitta, and Kafa. The functionality of these humours is the reason and cause for disease free or diseased body ${ }^{[4]}$.

Samanyavisheshsiddhant: ${ }^{[5]}$ This principle talks about food consumption. Consuming food having certain characters, increases the same characters in the body, this principle is known as Samanya. For instance, consumption of meat increases Mamsa of the body. Similarly, consumption of food containing opposite characters decreases those characters from the body, known as Vishesh. For instance, consumption of oil decreases Vata in the body as Vata contains dry character.

Rasa and Doshas: ${ }^{[6]}$ This principle states that the $R a$ $s a$ we consume affects the Doshas of the body. Sweet, sour and salty food items increase the Kafa in body and decrease the Vata. Bitter, spicy and astringent food items increase the Vata and decrease the Kafa. Similarly, sour, salty and spicy food increase the Pitta. Pathya and Apathy: ${ }^{[7]}$ According to this principle different food items and activities are defined as good or bad as per their impact on the body. Like sleeping in day is not suggested, use of black gram is not recommended in summers. Using green gram is good in most of the conditions and seasons. It is said that "No medication is require if one follows this principle and if avoided no medication will do."

Some Pathya and Apathy according to different season are as follow ${ }^{[8]}$

\begin{tabular}{|c|c|c|}
\hline Seasons & Pathya & Apathy \\
\hline Hemant & $\begin{array}{l}\text { Meat of animals with enough fat, wine, milk and its } \\
\text { products, fat, oil, new rice }\end{array}$ & $\begin{array}{l}\text { Food which increase Vata in body, light food, fasting, } \\
\text { powdered gram flour (Sattu) }\end{array}$ \\
\hline Shishir & All the food said above & All the food said above \\
\hline Greeshm & $\begin{array}{l}\text { Use of powdered wheat flour, meat of Jangal ani- } \\
\text { mals, old Shali rice, ghee and milk. }\end{array}$ & $\begin{array}{l}\text { Use of wine, spicy, bitter and astringent food, hot food, } \\
\text { exercise }\end{array}$ \\
\hline
\end{tabular}




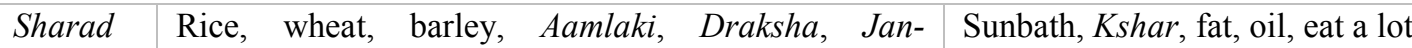
galmamsa, Hansodak

Three sub pillars of Ayurveda, ${ }^{[9]}$ this principle talks about immunity and health management. It states that food, sleep and sexual activities are the three sub pillars of life. Appropriate knowledge and use of these factors will lead to a balanced and disease-free life. Proper use of these 3 sub pillars and avoidance of bad food and activities alone can lead to a disease free and healthy life.

Aim \& objectives: Literary review of importance of Ayurveda in this covid-19 era.

\section{Material \& Methods}

- Literary review of the Ayurvedic preventive measures from different ancient Ayurvedic classical texts.

- Literary review of the curative approach in Ayurvedic texts.

- A case presentation of Indian Vaidya in NewYork covid-19 patient.

\section{Ayurveda's Prophylactic Approach}

Ayurveda has a broad category of techniques which can be used as prophylactic measures. This list consists of numerous methods and techniques that can help maintaining and achieving healthy lifestyle. This technique begins with the proper daily routine. In this chemical dominating era, it has become a prerequisite requirement to collaborate with Ayurveda for a better and convenient lifestyle. Some techniques of Ayurve$d a$ regarding preventive measures are:

Dincharya $^{[10]}$ i.e. day routine. Day routine as suggested by ancient Ayurveda scholars is as follows, waking up in Brahmmamuhurta, getting fresh, collyrium, nasal drop, mouth gargles, herbal smoking, consumption of beetle, massage, exercise and bath. Ritucharya ${ }^{[11]}$ i.e. Seasonal routine. According to this routine we should consume seasonal food and follow seasonal activities. Consumption of wine in winters, gram powder in summers and medicated water in rainy season is recommended. ${ }^{[12]}$ Another prophylactic approach is the proper way of having food ${ }^{[13]}$ like: quantity of food, sequence of having food, Anupana after having food and time of having food. All these factors impact digestion. The better the digestive system is, the lesser the disease will be and hence a promised immunity. Some other important methods include Use of proper spices ${ }^{[14]}$. Apart from taste spices contain enormous medicinal properties. For instances, antiseptic properties of turmeric, usage of asafoetida in digestion and stomach problems, black pepper as appetiser, Ajwain, fennel, black mustard seeds for betterment of heart. Use of herbal decoctions and rejuvenators ${ }^{[15]}$ is another and one of the commonly used measures for boosting immunity and preventing diseases.

\section{Ayurveda's Curative Approach}

After understanding the prophylactic approach of Ayurveda, now we will have a look at the curative approach. As per the rule if a person suffers from disease, he/she must be given proper medication. But Ayurvedic medication approach is based on some of the following principles.

Shodhan therapy ${ }^{[16]}$ (purification treatment): With this principle all the aggravated Doshas in the body are thrown out of system through different process as emesis, purgation, enema, etc. Second principle is Shaman therapy ${ }^{[17]}$ (palliative treatment) which is used to supress Doshas in the body with the help of medications. Third principle is Pathyavyavastha ${ }^{[18]}$ (prescription of diet and activity) through which the body maintains its working state without complications. Nidanparivarjan ${ }^{[19]}$ (avoidance of disease causing and aggravating factors) this is termed as the most basic principle of treatment. No medication will work until we restrict the use of causative factors. Satvavajaya, ${ }^{[20]}$ (psychotherapy) placebo effect is one of its type. Through this technique Mana is restricted to have harmful food and activities. Rasayana therapy [21] (use of immune modulators and rejuvenators) in these various immune modulators are used to enhance the immunity and hence keep diseases away.

\section{Clinical trials and medications regarding covid-19}

This covid19 period is the first time when Ayurveda is given permission of clinical trials in the modern era. Different medications for different symptoms of 
covid19 are suggested. Like the use of Sudarshanchurna, Vilbadigutika and Ashwagandadichurna for Jwara $^{[22]}$, use of Sitopaladichurna, Talishadichurna and Agastyarasayan for cough, Swas and different bodily pain. A lot of other formulations for mild to moderate symptoms of covid19 are described as well.

\section{A Case Presentation ${ }^{[23]}$}

A patient aged 43 years, an investor banker in New York, United States of America (USA), with a height of $193 \mathrm{~cm}$ and weighing $94.3 \mathrm{~kg}$ found corona positive. On the first day of falling ill contacted his Ayurvedic Vaidya in Chennai on the telephone, for a consultation and started on Ayurvedic medication for his complaints. A short summary of his recovery is as follow-

\begin{tabular}{|c|c|c|c|}
\hline Date/Day & Symptoms & Test/Result & Treatment \\
\hline $\begin{array}{l}29.03 .2020 / \\
\text { Day } 1\end{array}$ & $\begin{array}{l}\text { Severe body ache }(8 / 10 \text { on a scale of } 1- \\
10) \text {, } \\
\text { Abdominal pain }(2-3 / 10 \text { on a scale of } 1- \\
\text { 10), Temp: } 100^{\circ} \mathrm{F} \text {, Loss of taste and } \\
\text { smell }\end{array}$ & NA & $\begin{array}{l}\text { Day } \\
\text { Sudarsana Churna }{ }^{[24]} 4 \text { tablets } \\
(2 \text { gms }) \text { with room-temperature } \\
\text { water, Tid; } \\
\text { TalisadiChurna }{ }^{[25]} \text { 1tsp with hon- } \\
\text { ey, Tid; Dhanwantara Gutika }{ }^{[26]} 2 \\
\text { tablets, Tid, and regulated diet. }\end{array}$ \\
\hline $\begin{array}{l}30.03 .2020 / \\
\text { Day } 2\end{array}$ & $\begin{array}{l}\text { Immediately after starting the Ayurvedic } \\
\text { medicines, abdominal pain became very } \\
\text { mild. Body ache persisted. Temp: } \\
101^{\circ} \mathrm{F} \text {, Continued loss of taste and } \\
\text { smell, Mild coughing }\end{array}$ & NA & Same medicines continued \\
\hline $\begin{array}{l}31.03 .2020 / \\
\text { Day } 3\end{array}$ & $\begin{array}{l}\text { Severe body ache, Peak Temp: } 103^{\circ} \mathrm{F} \text {, } \\
\text { Continued loss of taste and smell, Severe } \\
\text { coughing. Cough was intermittent, dry. }\end{array}$ & NA & Same medicines continued \\
\hline $\begin{array}{l}01.04 .2020 / \\
\text { Day } 4\end{array}$ & $\begin{array}{l}\text { Severe body ache, Temp: } 102^{\circ} \mathrm{F} \text {, Con- } \\
\text { tinued loss of taste and smell, Severe } \\
\text { coughing. }\end{array}$ & NA & Same medicines continued \\
\hline $\begin{array}{l}02.04 .2020 / \\
\text { Day } 5\end{array}$ & $\begin{array}{l}\text { Body ache finally got better, Temp: } \\
100^{\circ} \text { F.Continued loss of taste and smell, } \\
\text { No coughing. }\end{array}$ & $\begin{array}{l}\text { Hometest: } \\
\text { CompletedCOVID-19 } \\
\text { Nasopharynx test: }\end{array}$ & Same medicines continued \\
\hline $\begin{array}{l}03.04 .2020 / \\
\text { Day } 6\end{array}$ & $\begin{array}{l}\text { No body ache, Normal temperature. Con- } \\
\text { tinued loss of taste and smell. }\end{array}$ & $\begin{array}{l}\text { doctor verbally confirmed } \\
\text { COV19 positive }\end{array}$ & Same medicines continued \\
\hline $\begin{array}{l}04.04 .2020 / \\
\text { Day } 7\end{array}$ & $\begin{array}{l}\text { Most symptoms disappeared except loss } \\
\text { of taste and smell. }\end{array}$ & NA & Same medicines continued \\
\hline $\begin{array}{l}\text { From } \\
05.04 .2020 \text { to } \\
\text { 12.04.2020: } \\
\text { Days } 8-15\end{array}$ & $\begin{array}{l}\text { Patient felt mostly normal, except for } \\
\text { loss of taste and smell. }\end{array}$ & $\begin{array}{l}\text { The written report for the } \\
\text { positive test result came } \\
\text { on } 07 / 04 / 2020 \text { (Day 10) }\end{array}$ & $\begin{array}{l}\text { From 11.04.2020/Day } 14- \\
28 \text { Vidaryadi } \text { Ghritam }^{[27]} 15 \mathrm{ml} \text {, } \\
\text { Bid }\end{array}$ \\
\hline $\begin{array}{l}13.04 .2020 / \\
\text { Day } 16\end{array}$ & $\begin{array}{l}\text { His sensation of smell was partially re- } \\
\text { stored. }\end{array}$ & $\begin{array}{l}\text { Patient ordered a home } \\
\text { test, the post fever } \\
\text { COVID } 19 \text { nasopharynx } \\
\text { sample was taken. Lab } \\
\text { said } \\
\text { "Insufficient material." }\end{array}$ & Same medicine continued \\
\hline $28.04 .2020 /$ & & Patient gave blood sample & Same medicine continued \\
\hline
\end{tabular}




\begin{tabular}{|l|l|l|l|}
\hline Day 31 & for testing. \\
\hline $01.05 .2020 /$ & Results: SARS-CoV-2 & NA \\
Day 33 & IgG, Num: 7.084 & \\
& NON-REACTIVE & \\
\hline
\end{tabular}

\section{DISCUSSION}

Ayurveda is a medicinal science, which promises better health conditions with least amount of complications. It has amazing results and is better suited. Herbal decoctions and rejuvenators are the future of medicinal science. They have great potency in immunity building and prevention of diseases ${ }^{[28]}$. Regular yoga and meditation are a key to a healthy lifestyle. Promotion of yoga nowadays is the indication of awareness of people regarding their health. Ayurvedic treatment consists of herbal meds which has least complications on the body. They just let the body heal all by itself therefore they are the way to natural healing of the body. Ayurveda in all of its aspects provides the best however it still requires that fame which it deserves. In this Covid-19 era many Ayurvedic Vaidya of different places of India, claim that they develop his own Samhita based combinations to treat this lifethreatening pandemic disease. When they are treating patients, they found that if patients follow the Ayurvedic lifestyle and preventive measures, they easily recover from the symptoms. One case of them, we share here and try to present the power of Ayurvedic treatment and lifestyle presentation which our Acharya's told in his Ayurvedic texts A long time ago.

In 1st day to 7th day's physician administrate Sudarsana Churna 4 tablets (2 gms), Tid with room-temperature water, Talisadi Churna 1tsp with honey, Tid, Dhanwantara Gutika 2 tablets, Tid, and regulated

diet. Sudarshan

Churna has Jwaraghna property which regulates the patient fever as well as controls the Abhyantar Daha, Bahya Daha, and Angmarda of the patient. Talisadi Churna has Kasaghna property and it also improves the digestion system which further eliminates the body and abdominal pain of the patient. Dhanvantar Gutika improves the respiratory system of the patient.
On 1st day a patient came with a history of severe body ache (8/10 on a scale of 1-10), abdominal pain (2-3/10 on a scale of $1-10)$, Temp: $100{ }^{\circ} \mathrm{F}$, Loss of taste and smell. After seven days of treatment patient, most of the symptoms disappeared except the loss of taste and smell.

From 8th to the 15th-day patient is administrated Vidaryadi Ghritam $15 \mathrm{ml}$ Bid. On the 16th-day patient taste and smell were partially restored. On the 33rd-day patient has no complaint as well as SARSCoV-2 IgG, Num: 7.084 NON-REACTIVE.

Ayurveda has developed a vivid analytical description of various stages and events taking place because the causative factors tend to operate till the final stages of a disease. This provides the system an added advantage of being aware of the possible onset of a disease much prior to the latent symptoms are apparent. This largely enhances this system's preventive role by making it possible to take appropriate and effective step well in advance so as to prevent further progress of the disease or to take proper therapeutic precautions to curb the disease in its early stage.

In today's we have to follow the Ayurvedic principles not only in diseased condition as well as in healthy condition. Ayurveda is science to live the healthy and diseases free life.

\section{CONCLUSION}

Ayurveda is a powerful medicinal tool known for its prophylactic technique. In these pandemic days, the world must understand this science and hence follow it. In this battle so far, Ayurveda has helped in various ways, from providing various decoctions and prophylactic techniques to treatment Ayurveda is trying its best to stand with its people in this hard time. Ayurve$d a$ is not only a science of medicine, but it is an art of living. But unfortunately, due to busy lifestyle people have forgotten about this art. Still in many parts of India people wake up at 4 A.M. and follow social dis- 
ciplinary action as per the ancient texts. Following these measures are self-sufficient to prevent pandemics or surviving in existing one. Hence one must understand and follow these life saviour principles of Ayurveda.

\section{REFERENCES}

1. Vidyadhar Shukla and Tripathi, Charak Samhita, reprint 2019, Chaukhamba Sanskrit Pratishthan, Varanasi: 2019, pg 567-572

2. Vidyadhar Shukla and Tripathi, Charak Samhita, reprint 2019, Chaukhamba Sanskrit Pratishthan, Varanasi: 2019, pg 447

3. Prof. Ajay kumarsharma, Kaya Chikitsa vol -1, Chaukhamba orientalia, Varanasi, Varanasi: 2019 pg- 78

4. Shailaja Srivastava, Ashtang Hirdayam, $2^{\text {nd }}$ edition, Chaukhamba orientalia, Varanasi, Varanasi: 2019 pg 78

5. Vidyadhar Shukla and Tripathi, Charak Samhita, reprint 2019, Chaukhamba Sanskrit Pratishthan, Varanasi: 2019 , pg 26-29

6. Shailaja Srivastava, Ashtang Hirdayam, $2^{\text {nd }}$ edition, Chaukhamba Orientalia Varanasi, Varanasi: 2019 pg 12

7. Vidyadhar Shukla and Tripathi, Charak Samhita, reprint 2019, Chaukhamba Sanskrit Pratishthan, Varanasi: 2019 , pg 336-337

8. Shailaja Srivastava, Ashtang Hirdayam, $2^{\text {nd }}$ edition, Chaukhamba Orientalia Varanasi, Varanasi: 2019 pg 44-59

9. Shailaja Srivastava, Ashtang Hirdayam, $2^{\text {nd }}$ edition, Chaukhamba Orientalia Varanasi, Varanasi: 2019 pg 132

10. Shailaja Srivastava, Ashtang Hirdayam, $2^{\text {nd }}$ edition, Chaukhamba Orientalia Varanasi, Varanasi: 2019 pg 27-37

11. Shailaja Srivastava, Ashtang Hirdayam, $2^{\text {nd }}$ edition, Varanasi: Chaukhamba Orientalia Varanasi, Varanasi: 2019 pg 46-57

12. Shailaja Srivastava, Ashtang Hirdayam, $2^{\text {nd }}$ edition, Chaukhamba Orientalia Varanasi, Varanasi: 2019 pg 46-57

13. Shailaja Srivastava, Ashtang Hirdayam, $2^{\text {nd }}$ edition, Chaukhamba Orientalia Varanasi, Varanasi: 2019 pg 141-144

14. Vidyadhar Shukla and Tripathi, Charak Samhita, reprint 2019, Chaukhamba Sanskrit Pratishthan, Varanasi: 2019 , pg 419-420
15. Dr. Guruprasad Sharma, Sharangdhar Samhita, Chaukhamba Krishnadas academy, Varanasi:2018

16. Vidyadhar Shukla and Tripathi, Charak Samhita, reprint 2019, Chaukhamba Sanskrit Pratishthan, Varanasi: 2019, pg 250

17. Vidyadhar Shukla and Tripathi, Charak Samhita, reprint 2019, Chaukhamba Sanskrit Pratishthan, Varanasi: 2019 pg 613

18. Vidyadhar Shukla and Tripathi, Charak Samhita, reprint 2019, Chaukhamba Sanskrit Pratishthan, Varanasi: 2019 , pg 336-337

19. Vidyadhar Shukla and Tripathi, Charak Samhita, reprint 2019, Chaukhamba Sanskrit Pratishthan, Varanasi: 2019 , pg 607

20. Vidyadhar Shukla and Tripathi, Charak Samhita, reprint 2019, Chaukhamba Sanskrit Pratishthan, Varanasi: 2019, pg 178-179

21. Vidyadhar Shukla and Tripathi, Charak Samhita, reprint 2019, Chaukhamba Sanskrit Pratishthan, Varanasi: 2019, pg- 334

22. Ministry of Ayush, interdisciplinary Ayush R\&D task force, guidelines for Ayush clinical trials in covid19, $2^{\text {nd }}$ April 2020-2 $2^{\text {nd }}$ may 2020, page 61/75

23. P.L.T. Girija, Nithya Sivan, Ayurvedic treatment of covid19/SARS-CoV2: a case report, journal of Ayurve$d a$ and integrative medicine.

24. Vd. Ramraksh Pathak, Ayurved Sar Samgrah, shri Baidyanath Ayurved Bhavan, Calcutta:2010, pg-598

25. Vd. Ramraksh Pathak, Ayurved Sar Samgrah, shri Baidyanath Ayurved Bhavan, Calcutta:2010, pg-584

26. Vd. Ramraksh Pathak, Ayurved Sar Samgrah, shri Baidyanath Ayurved Bhavan, Calcutta:2010, pg-469

27. Vd. Ramraksh Pathak, Ayurved Sar Samgrah, shri Baidyanath Ayurved Bhavan, Calcutta:2010, pg-673

28. Vidyadhar Shukla and Tripathi, Charak Samhita, reprint 2019, Chaukhamba Sanskrit Pratishthan, Varanasi: 2019 , pg-429

\section{Source of Support: Nil \\ Conflict of Interest: None Declared}

How to cite this URL: Sandeep Singh Tiwari et al: New Dimensions Of Ayurveda In This Covid-19 Era. International Ayurvedic Medical Journal \{online\} 2020 \{cited November, $2020\}$ Available from: http://www.iamj.in/posts/images/upload/2595_2600.pdf 